\title{
Joseph Brodsky And His Self-Translations
}

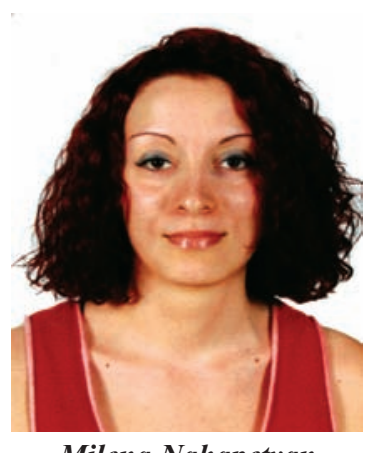

Milena Nahapetyan

Toseph Brodsky is known to be both a Russian and an American poet. He lived his life in Russia as well as in America. He used to write either in Russian or in English. Both his Russian and, especially his English have been criticized from different standpoints. Nevertheless, all critics admit Brodsky's high professionalism and unrivalled poetic talent.

Joseph Brodsky was born in Leningrad in 1940. He spent the first part of his life in Soviet Russia, writing poems in Russian. He is the author of the so-called genre of "grand poems". He became world famous after the trial in 1964, during which he was accused of decadence and parasitism and was sentenced to five years of labor camp in the region of Arkhangelsk. But with the help of his Russian and foreign colleagues he served in Arkhangelsk only for 17 months, after which he was forced to emigrate to the United States of America in 1972 as an involuntary exile from the Soviet Union. In the United States he became a "poet in residence", lecturing at Harvard University, Queens College, Mount Holyoke College, etc. While living in the States, Brodsky continued writing poems in Russian, and, simultaneously, he started writing prose, and especially essays, in English.

In 1987 J. Brodsky was awarded the Nobel Prize "for an all-embracing authorship, imbued with clarity of thought and poetic intensity". He was elected by the Library of Congress as Poet Laureate of the United States in 1992.

J. Brodsky's poetry has been published in twelve languages. His collections of poems include "A Part of Speech" (1977), "To Urania" (1987) and "So Forth" (1996). He has two published plays, "Marbles" (1986) and "Democracy!" (1992). His books of essays are entitled "Less than One" (1986), "On Grief and Reason" (1996) and "Watermark" (1992), the last one is a long essay on Venice. It's also worth mentioning that "Less than One" was named the best literary-critical book in 1986 in the United States.

As has already been mentioned, Brodsky used to write poems mainly in Russian and prose - mainly in English. At first, missing his parents and his native city, Brodsky went on writing Russian poems in the States. Later, aiming at sharing the singularity and the sense of his poems with the English-speaking community, he started translating many of his poems into English. Among others, the following self-translations can be mentioned: "May 24, 1980", "Elegy", "Folk Tune", "Letter to An Archeologist", "Seven Strophes", "To Urania", "From Nowhere With Love...", etc. Besides doing selftranslations, he also assisted translators in their efforts to translate his poems into English. One of Brodsky's self-translations is the poem entitled "May 24, 1980", which is presented below in its full size: 
I have braved, for want of wild beasts, steel cages, carved my term and nickname on bunks and rafters, lived by the sea, flashed aces in an oasis,

dined with the-devil-knows-whom, in tails, on truffles.

From the height of a glacier I beheld half a world, the earthly

width. Twice have drowned, thrice let knives rake my nitty-gritty.

Quit the country that bore and nursed me.

Those who forgot me would make a city.

I have waded the steppes that saw yelling Huns in saddles, worn the clothes nowadays back in fashion in every quarter, planted rye, tarred the roofs of pigsties and stables,

guzzled everything save dry water.

I've admitted the sentries' third eye into my wet and foul

dreams. Munched the bread of exile; it's stale and warty.

Granted my lungs all sounds except the howl;

switched to a whisper. Now I am forty.

What should I say about my life? That it's long and abhors transparence.

Broken eggs make me grieve; the omelette, though, makes me vomit.

Yet until brown clay has been rammed down my larynx,

only gratitude will be gushing from it.

Я входил вместо дикого зверя в клетку,

выжигал свой срок и кликуху гвоздем в ьараке,

жил у моря, играл в рулетку,

оведал черт знает с кем во фраке.

С высоты ледника я озирал полмира,

трижды тонул, дважды Бывал распорот.

Бросил страну, что меня вскормила.

Из заьывших меня можно составить город.

Я слонялся в степях, помнящих вопли гунна,

надевал на севя что сызнова входит в моду,

сеял рожь, покрывал черной толью гумна

и не пил только сухую воду.

Я впустил в свои сны вороненый зрачок конвоя,

жрал хлеь изгнания, не оставляя корок.

Позволял своим связкам все звуки, помимо воя;

перешел на шепот. Теперь мне сорок.

Что сказать мне о жизни? Что оказалась длинной.

Только с горем я чувствую солидарность.

Но пока мне рот не заьили глиной,

из него раздаваться вудет лишь Благодарность.

This is the first poem in Brodsky's collection of poems "To Urania", where it is presented in Brodsky's translation. Brodsky wrote this poem on the occasion of his $40^{\text {th }}$ Anniversary. In the poem he recollects the turning points of his life and analyzes them. Brodsky mentions about the prison ("I have braved $<\ldots>$ steel cages"); about being exiled ("carved my term and nickname on bunks and rafters"); refers to the time of immigration ("dined with the-devil-knows-whom, in tails, on truffles. / From the height of a glacier I beheld half a world"); mentions his attitude toward his homeland ("Quit the country that 
bore and nursed me. / Those who forgot me would make a city.") and finally, his attempts to forget all the bitterness he experienced ("guzzled everything save dry water").

The second part of the poem may be called a brief summary as Brodsky summarizes the turning points of his life and comes to certain conclusions. However, these conclusions are bitter: "What should I say about my life? That it's long and abhors transparence. / Broken eggs make me grieve; the omelette, though, makes me vomit.". Who would say at forty that his life has been long? Only a person who has suffered much; a person who sees no reasons for joy in this life. In this case "gratitude" seems a little strange, doesn't it?

The most interesting thing about this poem is that it is built on confrontation, contrast: Brodsky describes the "steel cage" of the labor camp, but after that comes the endless sea; the world from the top of the glacier is followed by descriptions of death; Brodsky says that he "munched the bread of exile" but then he uses the bookish "granted the lungs all sounds", etc. The intonation of the whole poem is also shifting - we can hear bitterness for the painful experience he has had, but it is mixed with the "gratitude" for just living. Thus, Brodsky summarizes his life - it has been long, but full of events, people, thoughts and feelings. And gratitude will be gushing from Brodsky's larynx until they are rammed down with brown clay.

Brodsky was very much criticized for this last sentence ("Yet until brown clay has been rammed down my larynx, / only gratitude will be gushing from it"). One of the critics wrote that it is an outrageous phrase and that Brodsky seems to talk about the blockaded Leningrad or state criminal camps in the north of Russia - Siberia. But there is an abstract in an article entitled "Brodsky and Translation. A Dual Mimesis" published in "An International Journal of Poetry, Translation and Art" by Daniel Weissbort that runs: "The first poem in "To Urania" is "May 24, 1980". It is translated by the author. Joseph marked it in my copy of the book, evidently proud, too, of what he had managed to achieve as a translator. Clearly he believed he had successfully demonstrated that rhetorically mimetic translation between Russian and English was possible".

Brodsky seemed to be satisfied with the quality of his work, otherwise he would not do it. But the feedback of the modern criticism for Brodsky's self-translations was not ordinary. Some critics responded positively, others were very unfavorable.

For example, one of the critics, who approved of Brodsky's self-translations, noted that he is "a brilliant self-translator of his own often brilliant poems". Derek Walcott said, "Joseph's poetry has enriched English 20 $0^{\text {th }}$-century poetry" (Walcott,1992). Daniel Weissbort writes: "what is surprising, perhaps, is how often Brodsky's competence was sufficient or how often he was able to fashion a self-consistent, if non-standard English text to match the Russian original. This highly intellectual poet was also working at a level almost of pure sound and movement" (Brodsky, 2001). The poet Lachlan Mackinnon refers to Brodsky's self-translations: "Those who complained about apparent technical deficiencies too easily forgot that Brodsky was engaged in creating a new idiolect, precisely the half-English of a deracinated man. $<\ldots>$ The resulting style is, while sometimes disconcerting, usually self consistent and achieved" (Mackinnon, 1996).

Conversely, some critics used to knock and criticize Brodsky's self-translations and his English, saying that the influence of Russian is huge. Brodsky was criticized for his 
attempts "to resurrect his Russian poems bodily. He tries to reproduce the structure of the original, its weight, and the physical place it makes for itself" (Brodsky, 2001). He cares "for the Russian text to be imported whole into English, in which case the target language would have to be Russianised and would be denatured". Among the most negatively disposed critics, who criticized Brodsky for his English, Christopher Reid and Craig Raine should be mentioned. Craig Raine even called Brodsky a "mediocre". The poet-translator Michael Hoffman, on the contrary, thinks that "even in English, Brodsky's poems have irresistible verbal authority, $<\ldots>$ because he wrote in such a way as to draw on American and Russian at the same time. There is something bipolar about the writing" (Hoffman, 1997).

M. Hoffman may have been closest to the truth - Brodsky, through his selftranslations, tried to express himself in Russian and American simultaneously. As to importing the whole Russian text into English, Vladimir Nabokov proclaims: "The person who desires to turn a literary masterpiece into another language, has only one duty to perform, and this is to reproduce with absolute exactitude the whole text, and nothing but the text. The term "literal translation" is tautological since anything but that is not truly a translation but an imitation, an adaptation or a parody" (Weissbort, 2003).

Whatever the opinions of critics are, we are inclined to think that Brodsky's selftranslations are very skillful and of special value from the linguistic point of view. They create links between the two most popular world languages. Besides, these selftranslations are a good opportunity for non-Russian speakers to get acquainted with the works of the famous Russian-American poet, Nobel Prize Laureate Joseph Brodsky.

\section{References:}

1. Brodsky J. The Collected Poems in English. New York: Farrar, Strauss and Giroux, 2001.

2. Hoffman M. On Absenting Oneself. // Times Literary Supplement, London: News International, 1997, January 10.

3. Mackinnon L. Joseph Brodsky. // The Independent, London, 1996, March 23.

4. Walcott D. Brodsky through the Eyes of his Contemporaries. ed. by V. Polukhina. London: Palgrave Macmillan, 1992.

5. Weissbort D. Brodsky and Translation. A Dual Mimesis. // An International Journal of Poetry. Melville, New York: Translation and Art, 2003, December, Vol. 1.

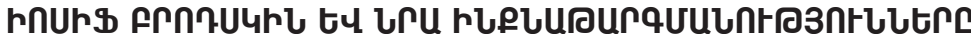

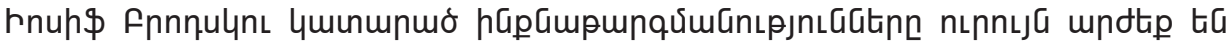

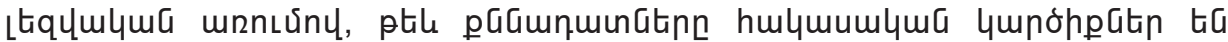
hujunfitis nnuilg vimuha: 